\title{
USING COMMUNICATIVE LANGUAGE TEACHING (CLT) APPROACH THROUGH SMALL GROUP DISCUSSION AS A DEVICE TO STIMULATE THE STUDENTS TO SPEAK IN ENGLISH Penggunaan Pendekatan Pengajaran Bahasa Komunikatif Melalui Diskusi Kelompok Kecil Sebagai Sebuah Alat Untuk Menstimulasi Mahasiswa Berbincang Dalam Bahasa Inggris
}

\author{
Muhammad Astrianto Setiadi \\ English Education Department, Faculty of Teacher Training and Education \\ Muhammadiyah University of Makassar \\ astriantosetiadi@gmail.com
}

\begin{abstract}
This study was conducted to find out whether or not the using of Communicative Language Teaching (CLT) Approach through Small Group Discussion effective to stimulate the students to speak in English than the conventional way, and also to improve the teacher awareness to use an effective approach in teaching English especially in teaching speaking skill. This study employed a Pre-Experimental research method with One Group Pre-test and Post-test Design. The data obtained from the test was analyzed quantitatively and then it's result was compared with questionnaire to know whether the students interested in learning speaking by using Communicative Language Teaching (CLT) Approach or not. The mean score obtained from Pre-test was 2, 84 and post-test was 6, 01. The data showed that the student's speaking skills in post-test was higher than the pre-test. The data obtained from questionnaire showed the mean score 78, 67. It means that the students were highly interested to the application of speaking materials through Communicative Language Teaching Approach through small group discussion.
\end{abstract}

Keyword: Communicative Language Teaching Approach, Small Group discussion, speaking.

Penelitian ini dilakukan untuk mengetahui penggunaan dari Pengajaran Pendekatan Bahasa Komunikatif (CLT) melalui Diskusi Kelompok Kecil efektif untuk merangsang siswa untuk berbicara dalam bahasa Inggris dari pada cara konvensional, dan juga untuk meningkatkan kesadaran guru untuk menggunakan pendekatan yang efektif dalam mengajar bahasa Inggris terutama dalam mengajar keterampilan berbicara. Penelitian ini menggunakan metode penelitian Pre-Eksperimental dengan Satu Group Pre-test dan Post-test Design. Data yang diperoleh dari tes dianalisis secara kuantitatif dan kemudian itu hasil itu dibandingkan dengan kuesioner untuk mengetahui apakah siswa tertarik untuk belajar berbicara dengan menggunakan Pendekatan Pengajaran Bahasa Komunikatif (CLT) atau tidak. Skor rata-rata yang diperoleh dari Pre-test adalah 2, 84 dan post-test adalah 6, 01. Data menunjukkan bahwa keterampilan berbicara siswa dalam post-test lebih tinggi dari pre-test. Data yang diperoleh dari kuesioner menunjukkan mean skor 78, 67. Ini berarti bahwa siswa yang sangat tertarik untuk penerapan bahan berbicara melalui Pengajaran Bahasa Komunikatif Pendekatan melalui diskusi kelompok kecil.

Kata Kunci: Komunikatif Pengajaran Bahasa Pendekatan, diskusi kelompok kecil, berbicara.

Speaking is expressing the student's performance, they are mostly inhibited by some obstacles emotionally in teaching and learning process such as the students anxious and nervous to convey their ideas and thought, the students do 
not have comfortable interaction process to communicate with their friends or their teacher, and the students are afraid in making mistakes to speak. These are to say that the students mostly faced by anxiety disorder.

Usually the students do not participate actively in speaking class. Probably because they are lack of knowledge, they are not hear the topic, they have no ideas toward the subject matter, the teacher dominates in the classroom. All information will come from the teacher, interaction between or among the students is less values, the students are uninteresting from the topic, and sometimes the subject is not concentrate.

Facing these realities, learning to speak needs a great focus and attention from the teacher properly, and for this purpose, to raise this improvement, the purposes Communicative Language Teaching approach through small group discussion as a possible solution. In this approach "communication" means using language to make request, give advice, agree and disagree, complain, praise, to try to persuade people to do things, a and so on. The focus should be on meaning, not on form.

John Trims (1997:21) one of founder of CLT, has said that "students learning in school must be taught that language learning is about communicating, not getting things right". Trims believe in "emphasizing the importance of repair strategies and of the acceptance of errors". He asked "if justified in attempt to put them right, instead of developing different ways or enlarging that person's communicative range? Instead of correcting mistake, we should be doing thing that will extend the communicative range of learners. To some extent, the way of teaching English also influence the student's motivation and technique how to make the students more interested in learning and teaching process. One way that should be done by the teachers is how to encourage the students to speak in English by selecting an interesting topic to be discussed in the small group discussion. Hereby with the use of Communicative Language Teaching approach through small group discussion is expected that the students will have good competency in speaking English. 


\section{WHAT IS SPEAKING}

Speaking is an interactive process of constructing that involves producing and receiving information (Brown, 1994; Burns and Joyce, 1997). Its form and meaning are dependent on context in which it occurs, including the participants themselves, their collective experiences, the physical environment, and the purposes for speaking. It is often spontaneous, open ended and evolving. Pesola (1995) defines speaking as a means of oral communication to other or speaking is a way to bring message from one person to others in order to interact with them. Communication is a collaborative venture in which the interlocutors negotiate meaning in order to achieve their communicative purposes.

Sauvignon (1997) points that for most of its history, language teaching has been concerned with teaching of written language. This characterized by wellformed sentences, which are integrated into highly short often-fragmentaryutterances, in a range of pronunciation. There is often a great deal of reputation and overlap between one speaker and another speaker frequently use non-specific reference.

Scarcella (1992) suggests that oral interaction can be characterized in terms of routines, which are conventional ways of presenting information, which can either focus on information or interaction. The successful communication can be seen when mutual understanding between speaker and listener in exchanging ideas work as their wish. Ur (1992:120) classified the characteristics of successful speaking ability, they are:

a. Learners talk a lot

b. Participation is even

c. Language is of an acceptable level

The role of material in learning speaking is also needed. The key of speaking material which is decided by the speaker, the material determines the success of communication so the material should be interesting for both of the speaker by having the materials in teaching-learning process, we have made the student interact with the world of speaking in order to broaden their knowledge.

Harmer (1995) states that when two people are engaged in talking to each other we can be fairly sure that they are in general ways to suggest to a speaker 
makes a definite decision to address some one. Speaking may be forced on him in some ways but we can still say that wants or intends to speak, otherwise he would keep silent. He has some communicative purposes; speaker say thing because want something to happen as result of what they say. He selects from his language store. The teacher has an infinite capacity to create new sentences if he is a native speaker. Skill will be focused for the first section on speaking.

\section{THE ELEMENTS OF SPEAKING}

\section{a. Pronunciation}

Cheet Mayers (1993:13) states that it is the fact or manner of pronunciation something: articulate utterance. Certainly, pronunciation cannot be separated from intonation and stress. Pronunciation, intonation and stress are largely learnt successfully by imitating and repetition. Therefore, the teacher in any teaching and learning process, but we cannot expect our student to exactly and like an American or Britain and teacher should introduce activities will be done in order to give them opportunities to make a lot of repetition.

\section{b. Vocabulary}

Vocabulary is a fundamental requirement that influence students' achievement in studying English. Without vocabulary there is no communication, read, and write can be conveyed. So that, it is important to know what the vocabulary is.

Hornby (1968:959) defines vocabulary as:

1. Total members of words, which make up a language.

2. Range of words known, or used by a person in a trade, profession, etc.

3. Book containing a list of words, list of words used in a book, used with definition and translation.

Cheet Meyers (1993:15) states that it is a words and phrases usually alphabetically arranged and explained or designed. Furthermore, Jeremy harmer (1991:14) distinguishes two types of vocabulary in the word, which students will vocabulary. Active vocabulary and use themselves, and passive vocabulary is the words, which we want student to understand, but they will not use themselves. 


\section{c. Accuracy and fluency}

Hornby (1987:9) states that accuracy is the states of being or exact and without errors, especially as result of carefully effort. Some students always seem to speak too loudly, while other seems to speak in a whisper.

\section{COMMUNICATIVE LANGUAGE TEACHING}

Curtain H Pesola (1994) defines Communicative Language Teaching as a contextual and actual approach used to guide students to communicate in various classroom activities. In another sense, Haas M (1999) states that Communicative Language Teaching is a learning process, which is involves the various activities to do communication that take place in the classroom activity. In addition, Scarcella (1992) defines Communicative Language Teaching as theoretical devices in conducting learning teaching process through various communicative activities.

In CLT, "communication" means using language to make request, give advice, agree and disagree, complain, praise, to try to persuade people to do things, and so on. The focus should be on meaning, not on form. Some supporters of CLT, as Geoff Thompson (1992) argue that this is misconception of CLT. However, even he admits that there are good reasons for this "misconception". Therefore, language is primarily a tool communication. Learning a language means learning to perform communicative speech act with it.

Based on the some views above presented by some linguists, we can conclude that Communicative Language Teaching (CLT) is a very closely related with various activities used by the teacher in teaching language through communicative approach where the teacher created language immersion setting in the classroom, planned lesson around themes that were interesting to the students, asked the students to think critically, reinforced concept and skills from the regular classroom, integrated culture, and gave students opportunities to use the target language in a variety situations.

\section{COMMUNICATIVE LANGUAGE ACTIVITIES}

Here is some activities are all designed to provoke the students spoken communication between student and/or between the teacher and the students. We will divide the activities into seven categories: reaching consensus, discussion, 
relaying instruction, communication games, problem solving, talking about yourself, simulation and role play. Where the organization of the activities seems complicated, teaching stages have been included.

\section{Reaching a consensus}

Reaching a consensus played where the students have to agree with each other after amount of discussion. The task is not complete until the do. Students are giving a situation are given. There are many occasion when we will ask students in groups to come to a consensus about things they are learning. Reading task may involve this kind of agreement (students decide which is the correct answer together); some vocabulary study involves reaching consensus about which meanings are correct or which word for comprehension work.

\section{Discussion}

Discussion means talk between people, a talk between two or more people about subject, usually to exchange ideas or reach a conclusion, or talk of this kind. Many teachers can be heard complaining that their students 'have nothing to say' they complain, for example, that they have no opinions and are not prepared for discuss anything. Part of the problem here is the way in which some teachers approach discussion as an activity. If students are asked to express themselves fluently on a difficult topic in front of their peers in a foreign language (often no warning) they may find themselves reluctant to do so.

\section{Relaying instruction}

In this type of activity students have to give each other instruction. The success of the activity depends on whether the students to whom instructions are being given perform the tasks successfully in other word, where the instruction the right ones, and where they understood.

\section{Communication games}

Communication games are based on the principle of information gap. Students are put into a situation in which they have to use all or any of the language they possess to complete a game like task. 


\section{Problem solving}

Problem solving activities encourage students to talk together to find a solution to (a set of) problems or task.

\section{Talking about yourself}

The student they are often an underused resource: in particular we can use their lives and feelings for any number of interpersonal exchanges. Such activities fall into the "Humanistic' category and are often useful at the beginning of classes to warm things up or to create a good and positive atmosphere in new groups which are a bit 'icy' (ice breakers)

\section{Simulation and Role play}

The idea of simulation is to create the presence of a real situation in the classroom; students simulate the real world. Thus we can ask them to pretend that they are at an airport, or we might ask them to get together to plan an imaginary reunion, what we are trying to do-artificial of course to give students practice in the real world English.

\section{SMALL GROUP DISCUSSION}

According to Kagan S (1998) small group discussion is a discussion done to talk about a given topic by small group of people. He then adds that there some point are necessary to be observed before doing the discussion such as; generate ideas in preparation for a lecture, film, etc.; reexamines ideas presented in previous classes; review exams, problems, quizzes and writing assignment; process learning outcomes at the end class; compare and contrast theories, issues, and interpretations; solve problem that relate theory to practice; and brainstorming application of theory to life.

\section{THE PPRACTICAL ACTIVITIES OF SMALL GROUP DISCUSSION}

It is necessary for the teacher of English to spend much time to think about the way that the teachers can act on their recommendations. To the extent that the teacher can meet the objectives, the teacher will enhance communication skills that are value in the classroom now. These skills also viewed favorably by employers in the future. The practical activities of small group discussion as follows:

Positive interdependence: The group sinks or swims together. 
The teacher achieve this goal i small group discussion in the courses when each group member shares a group task, a mutual goal, and common resources (a shared text or problem).

Face-to-face interaction and advocacy: Students help each other learn.

The teachers achieve the goal of assisting, encouraging, and supporting each other in learning by the way of the teacher structures their classroom seating. Students are more able to learn together when they face each other in the small circle. Students also support each other in learning when they make a commitment to solve problem jointly through discussion and shared explanation. At first the teacher may be disconnected by group discussion. Sometimes students in the class who have never participated in small group approach their assigned task in highly individualistic ways. For example, rather than work together or a series of questions they have been asked to discuss, they decide that each student will work alone on one of the question and share her/his answer with the others. The teacher discourages the privatizations of group work. More effective cooperative learning occurs when students maintain a commitment to sharing insight with each other. Four or five heads are better than one when it comes to responding to an assignment.

Individually accountability: each group members has a responsibility to contribute to the group and do her/his "fair share". When students exercise the roles, they develop skill in leading, making decisions, building trust, and managing conflict. All these skills are value in today's workplace.

\section{METHODOLOGY}

The method employed in this research was a Pre-Experimental Design research method that applied the one-Group pretest-posttest Design (Gay, 1981:224). This design involves one group of 39 students of the second semester of English Education department of FKIP Unismuh Makassar in 2006-2007 academic years. They were administered pre-test and post-test, where the pre-test was administered before giving treatment and post-test after giving treatment. The group received treatment by using Communicative language Teaching (CLT) Approach through Small Group Discussion in learning Speaking. The group was decided from the population by using total sampling technique. 
In collecting data, the writer gave a speaking test that was speaking performance in oral form test to know the students speaking skills. The students were given a topic to talk over which consist of three sub topics. In assessing the students' progression during learning speaking materials through Communicative Language teaching approach, the writer used speaking assessment of speaking performance. The assessment was divided into four categories; they were the assessment of vocabulary, grammar, effectiveness, and pronunciation. Each category has different way in scoring the students achievement.

\section{FINDINGS AND DISCUSSION}

The findings consist of the data contained through achievement test to know the students achievement after being taught the Communicative Language Teaching Approach of the speaking performance through small group discussion. Some findings could be drawn up. The application of communicative Language Teaching could stimulate the students' interest on their speaking performance to the good accuracy and fluency with the speaking test. Its indicated by the significant difference between the score of their pre-test and post-test of the experimental group as shown from the students' score in the pre-test $(2,83)$ is different from the post-test $(6,01)$. This means that the use of Communicative Language Teaching could stimulate the students' speaking performance. To be clearer, the researcher presents the specific data as shown below:

Table 1. The Students' Speaking Performances

\begin{tabular}{|l|c|c|c|c|c|c|}
\hline \multicolumn{1}{|c|}{ Test } & Vocabulary & Grammar & Effectiveness & Pronunciation & X1 & Mean score \\
\hline Pre-test & 144 & 136 & 131 & 147 & 139,5 & 2.83 \\
\hline Post-test & 316 & 289 & 326 & 311 & 297 & 6.01 \\
\hline Aggregate & 172 & 126 & 195 & 164 & 157.5 & 3.18 \\
\hline
\end{tabular}

The table above shows the aggregate the score between the four aspects of speaking test both in pre-test and post-test of control group. The data indicates that all aspects show higher score in posttest. The data obtained from the questionnaire shows that the students are highly interested to the application of speaking material through Communicative Language Teaching with Small Group Discussion. It is proved by the mean score of the students' interest. 
Table 2. The Students' Interest

\begin{tabular}{|c|l|c|c|c|}
\hline \multirow{2}{*}{ No } & \multirow{2}{*}{ Category } & \multirow{2}{*}{ Scores } & \multicolumn{2}{c|}{ Students' interest } \\
\cline { 4 - 5 } & & & Number & Percentage \\
\hline 1. & Strongly interested & $85-100$ & 2 & $4,08 \%$ \\
\hline 2. & Interested & $69-84$ & 37 & $95,2 \%$ \\
\hline 3. & Moderate & $52-68$ & 0 & 0 \\
\hline 4. & Uninterested & $36-51$ & 0 & 0 \\
\hline 5. & Strongly interested & $20-35$ & 0 & 0 \\
\hline \multicolumn{3}{|c|}{ Total } & 49 & $100 \%$ \\
\hline
\end{tabular}

The table above presents the students' interest data in the form of quantity and percentage. After being tabulated, the students' interest data shows that most of students are classified into interest category and the rest are in strongly interested category. Finally, the table result describes that the use of CLT through small group discussion could stimulate the students' interest in learning English speaking skills.

\section{CONCLUSION}

Based on the research findings and discussions, the conclusion of this study is stated into the following statements:

1. The research findings were taken from students through treatment. Pre-test and post-test were the instrument used to find out the students' achievement by analyzing their speaking improvement into percentage. The result of the data shows that percentage of the students' speaking achievement in post-test higher that in pre-test $(6,41>2,84)$. It proves that, the application of Communicative Language Teaching (CLT) in learning English speaking performance could stimulate the students in learning the materials of speaking performance.

2. The findings of the students' interest toward the use of CLT in learning speaking performance show a good result. The data tabulated through questionnaire presented the classification of the students' interest are put in agree $(95,2 \%)$ and strongly agree $(4,8 \%)$. It proves that the use of CLT in learning speaking performance could stimulate the students'; interest.

\section{REFERENCES}

Cheet, Mayers. 1993 Collaborated Learning New Jersey: Laidlaw Brothers Company.

Sauvignon S.J. 1997. Communicative Competence Theory and Classroom Practice. New York Mac Grow Hill. 
DEPDIKNAS, 2005. "Assessment and Evaluation” diklat Manajemen Sekolah Bagi Kepala Sekolah/wakil SMK, Guru Matematika dan Bahasa Inggris.

Harmer Jeremy, 1991. Gay 1981The Practice of English language Teaching. Longman.

Layman, 1972. Technique in Testing. New York: Oxford University Press.

Gay.L.R.1981 Educational Research: competency for analysis and application. Florida: A Belt and Howell Company.

Marcel.1978 English Speaking Elements. Last update June, 12th 2006 Available on: http://eng.udu.gsu.edu /mos-dos/9.html.

Pesola.C.AD 1995 Background. Design and Evaluation of a Conceptual Framework for FLESH Curriculum. Brown and Company. Boston, Toronto.

Rasyid, MA. 1998. The Teaching of Speaking to the First Semester Students of English at IKIP Ujung Pandang. Unpublished Thesis PPS. UNHAS.

Richard, Jack C. And Rodgers, Theodore S. 1995. Approach and Method in Language Teaching. Melbourne: Cambridge University Press.

Scarcella R, and Oxford 1992. The Tapestry of Language Learning: Boston: Heinle.

Soba. 2005. Building up The Students Speaking Performance through Guided Dialogue. Unpublished Thesis PPS. UNM. 